\title{
個人の不安特性が甘味感受性におよぼす影響
}

\author{
加藤みわ子* ・伊藤康宏 ${ }^{* *} \cdot$ 永 忍夫**・清水 遵***
}

(*愛知淑徳大学コミュニケーション研究科, **藤田保健衛生大学衛生学部,

***愛知淑徳大学コミュニケーション学部)

\section{Effect of A-Trait personality on sweetness taste preferences}

\author{
Miwako Kato*, Yasuhiro Ito**, Shinobu Naga**, Jun Shimizu***
}

*Graduate School of Communication Studies, Aichi Shukutoku University, 9 Katahira Nagakute, Nagakutecho, Aichi-gun, Aichi, 480-1197, Japan

**School of Health Science, Fujita Health University, 1-98 Dengakugakubo,Kutsukake-cho, Toyoake, Aichi, 470-1192, Japan

***Faculty of Communication Studies, Aichi Shukutoku University, 9 Katahira Nagakute, Nagakute-cho, Aichi-gun, Aichi, 480-1197, Japan

*,***T480-1197 愛知県愛知郡長久手町長湫片平 9

**干470-1192 愛知県豊明市沓掛町田楽ヶ窪 1-98

\begin{abstract}
The influence of trait anxiety on food taste preferences was investigated in 73 healthy university students (age 21.3 \pm 0.5 years). Participants were divided into two groups (A-Trait group and Normal group) based on their State-Trait Anxiety Inventory scores and both groups were tested for sensitivity to sweet, sour and salty tastes. Participant's emotions were assessed using the Affect-grid, and chronic stress was assessed using the Cumulative Fatigue Symptoms Index. The results of comparing test scores between the two groups indicated that the A-Trait group, in comparison to the Normal group, had a significantly higher sensitivity to sweet taste $(\mathrm{t}(61)=$ $2.72, \mathrm{p}<0.01)$. Also, the A-Trait group, compared to the Normal group, had a significantly higher arousal level $(\mathrm{t}(66)=2.04, \mathrm{p}<0.05)$ and a significantly higher chronic stress level $(t(71)=3.02, \mathrm{p}<0.05)$. Moreover, arousal level $(\mathrm{r}=0.30, \mathrm{p}<0.05)$ and chronic stress level $(r=0.56, p<0.01)$ were correlated with trait anxiety. It is concluded that people with trait anxiety feel more stress and preferred sweet tasting food, suggesting that trait anxiety causes changes in eating habits.
\end{abstract}

\section{緒言}

平成 12 年 3 月に文部・厚生・農林水産の 3 省（当時） により, 誰もが食生活改善に取り組めるように配慮され た目標として「食生活指針」1)が策定された。指針では, ライフスタイルの多様化による食生活の偏り, 食への誤 った理解などから引き起こされる健康障害も大きな問題 とされ，栄養失調や拒食症などの食行動異常へ警鐘を鳴 らしている。野口ら（1998）による過敏性腸症候群の経 過中に食事制限や偏食の末に体重減少をきたし, 神経性 食欲不振症になった例の報告 2 は, 「偏食の自由」の危 険性を訴えるものであろう。偏食の自由とは，いつでも
何でも食べることができるという心理的安心感, 飽食感 に満ちた現代3)に生まれ育った若者の身についている “食事は自分の勝手で, 好きなものを好きなように食べ ることが当然だ”とする考え方である4)。また，短大生 の食生活と体調に関する調査（深見ら，1996）では, 若 者がほとんど摂取していない食品に大豆製品, 海草類, 緑黄色野菜, 魚介類が示され, 若者の偏食実態が明らか となった。若者の体調については，何となくだるい，ね むいとの訴えが強い。これらの体調不良は, 偏食による ビタミン類の不足によると考えられ, 食生活改善が求め られている5)。

偏食を生み出す要因として，食物を嫌いになる原因の 
多くは「味」にある5)。しかし, 飽食・美食の時代にあ る若者の偏食傾向が食品そのものの味に影響していると は考え難い。富田ら（1992）は, 一見健康そうな大学生 男女のうち, 約 $20 \%$ が簡易味覚検査で異常を認めた6) と しており，偏食傾向に若者の味感受性（味覚）が影響し ている可能性が疑われる。若者を取り囲む現代社会には, 不確実で, 不安定な要素が多く, 物質的な豊かさの陰で, 人々を寂しさと不安に陥れる要因が少なくない。我が国 では1970年代から摂食障害患者が増加しており, 要因と して藤内ら（2002）は, 低い自尊心, 不安と隣り合わせ の完璧主義, 自律の葛藤, 同一性の拡散など思春期特有 の問題がストレス状態を生み出し, 患者は現実的に合理 的に解決することの代わりに, 不適切なストレス対処行 動としてのダイエットによる体重軽減から成功感やセル フコントロールの実感を手に入れようとしていると述べ ている7)。すなわち, 不安感が強いことが食行動異常を 引き起こす要因のひとつであると考えられる。食欲が気 分によって左右されることも, さまざまな研究により示 されている。しかしながら, 気分と食物摂取に関しての 多くの研究は抑うつ状態に集中している8),9)。

そこで, 本研究では気分の中でも多くの若者が抱いて いると考えられ，摂食障害の要因の一つである不安感に 着目をした。また, 若者の偏食傾向を左右する因子の中 で味覚が大切であると考えた。味覚は, 物質の味を評価 し，質を識別する感覚であり，食物を選択する基本的な 行動の動機となる。したがって, 味覚を保持することが 適切な食行動をもたらす。そこで本研究では, 不安感が 味覚, ストレス感におよぼす影響を検討し, 食を通した 生活の質（QOL）の向上を考えた。

\section{実験方法}

\section{1. 実験参加者}

承諾を得た健常な大学生73名（女性52 名, 男性 21 名, 平均年齢 $21.3 \pm 0.5$ 歳 $)$ が本研究に参加した。

参加者には, あらかじめ実験の日時を知らせ, 実験に 食事の影響がないように実験開始前 1 時間の飲食を控え るように教示した。また, 実験開始前に, 水道水で口腔 内を洗浄することを求めた。

\section{2. 実験方法}

実験参加者を不安の特性の強さによって 2 群に分け, 味覚試験を行い塩味, 甘味, 酸味の感受性の違いがある かを検討した。また，すべての参加者の感情と慢性的な ストレス感を質問紙により評定した。

不安の特性 : 性格特徵の中で一貫して出現する行動傾 向やそのまとまりである個人特性を測定するために, 参 加者全員に日本版状態 ·特性不安インベントリー (State Trait Anxiety Inventory；以下 STAI と略す) ${ }^{10)}$ に回答を求めた。STAI は, スピルバーガーらが作成し, 水口ら（1999）が日本語版を刊行した自己評価型不安尺
度の一つである。STAI は広く臨床や心理療法場面でも 用いられる検査法であり, 刻々变化する不安状態 (状態 不安）と不安になりやすい性格傾向（特性不安）を分け て測定できるという特徵がある。本研究に㧍いては, STAI の個人特性としての不安傾向である特性不安 （STAI-II；A-Trait）の20項目を 4 段階評定により選 び○付け回答したものを, STAI の計算方法に準じて採 点した（得点範囲20〜80点）。特性不安得点について, STAI の正常成人の基準点に基づいて，女性は45点以上， 男性は44点以上を「高不安群」とし, 基準点に満たない ものを「健康群」と定義した。

味覚試験：味覚試験は, 基本 5 味（甘味・塩味・酸味· 苦味・うま味) のうち, 甘味・塩味・酸味の3 味とした。 試料については, 溶質が実際の料理に必要な呈味の内容 になるべく近くなるように, 甘味には砂糖, 塩味には天 塩, 酸味には醸造酢（米酢）を使用した。味濃度はそれ ぞれ，ごく薄い濃度から 6 段階の $(0.0 ， 0.1 ， 0.2 ， 0.4$, $0.6 ， 0.8$ (重量\%)）の濃度勾配 ${ }^{11)}$ をつけた（表 1 ）。試 料担体として寒天（岐阜県恵那市山岡町産）を用い約 4 \%で固化した。実験の流れは, ランダムに並べて提示さ れた試料を, 参加者が一定量（10.7g/回）呈味した後, 試食ごとに味覚官能試験用紙に記入し, 次の味試験に移 行した。官能試験用紙には，「味を感じた（1 点）か, 感じなかった（0 点）か」を参加者自身が $\bigcirc \times$ で記入回 答した。すなわち, 各系列について味ごとの合計得点の 高い方が感受性が高いことを示す。また, 試験時の試料 温度は, $28 \pm 3{ }^{\circ} \mathrm{C}$ 。試験室の室温は $28^{\circ} \mathrm{C}$, 湿度は $53 \%$ で あった。

表 1 試料の濃度勾配

(重量\%)

\begin{tabular}{cccccccc}
\hline 味の種類 & 溶質 & 濃度 1 & 濃度 2 & 濃度 3 & 濃度 4 & 濃度 5 & 濃度 6 \\
\hline 甘味 & 砂糖(上白糖) & 0.0 & 0.1 & 0.2 & 0.4 & 0.6 & 0.8 \\
酸味 & 醸造酢(米酢) & 0.0 & 0.1 & 0.2 & 0.4 & 0.6 & 0.8 \\
塩味 & 食塩(天塩) & 0.0 & 0.1 & 0.2 & 0.4 & 0.6 & 0.8 \\
\hline
\end{tabular}

感情評定 : 実験時の気分を評定する目的で, アフェク

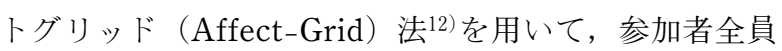
の快一不快感および, 覚醒-不覚醒感を測定した。本研究 では, 横軸は「快-不快」, 縦軸は活動性を示す「覚醒一 不覚醒」の 2 次元からなるアフェクトグリッドを用い, 各次元について，1 から 9 までの 9 段階で回答を求めた (図 1 )。本研究では, 参加者の “感情” を扱う特徵上, 参加者が瞬時に判断できる測度としてアフェクトグリッ ドが最適であると判断した。

自覚的ストレス評価 : 慢性ストレス状態を評価する目 的で作成された, 蓄積的疲労徵候インデックス（An Index of cumulative fatigue symptoms; 以下 CFSI と略 す) 13)を用いて, 日常的な心身の状態を参加者が主観的 に評価した。CFSIは，何日間か停滞して感じるような 症状 · 状態, または時々感じる心身の違和感を尋ねるも 


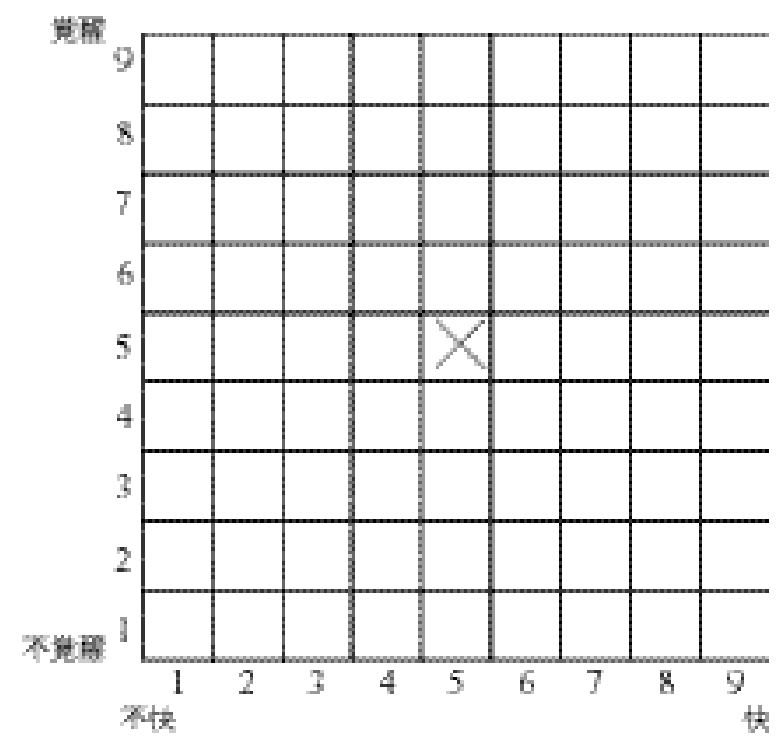

図1アアフェクトグリッド評価表

ので81項目からなる。参加者は, これら81項目にあては まる $(○)$, あてはまらない $(x)$ の 2 評定法で回答し た。本研究では, CFSI の採点方法に準じて採点した (得点範囲 $0 \sim 800$ 点)。

\section{結果}

甘味・塩味・酸味それぞれに関して, 高不安群と健康 群を比較した。このとき，哭煙，薬物摄取などの味覚に 影響することが知られている要因を有する者は味覚試験 から除外した。また，味覚試験の回答に不備のあった 12 名を除外した（健康群のうち甘味 1 名, 塩味 3 名, 酸味 2 名, 高不安群のうち甘味・塩味・酸味各 6 名)。味覚 試験ごとの群別の平均値は図 2 に示した。

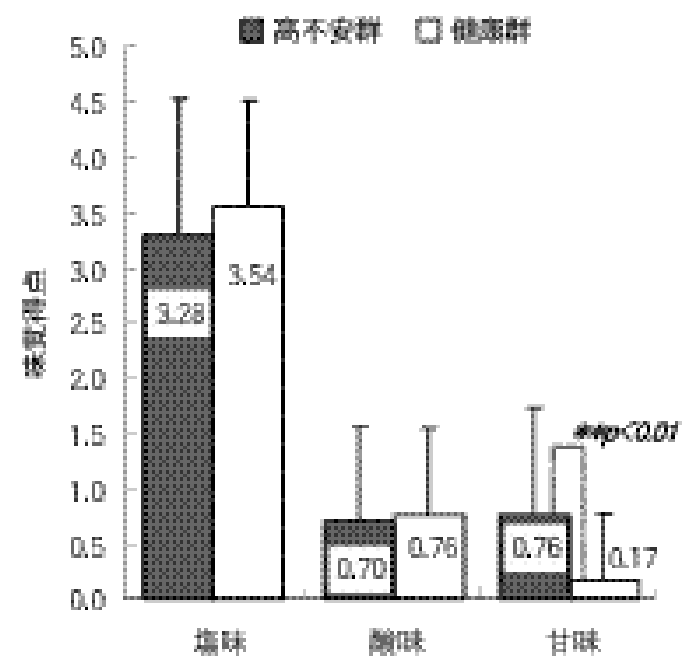

図 2 高不安群之健康群の味覚感受性比較

\section{1. 特性不安}

特性不安得点に基づき参加者を 2 群に分けた結果，高 不安群43名（女性32名（Trait $54.8 \pm 7.5$ 点）, 男性11名

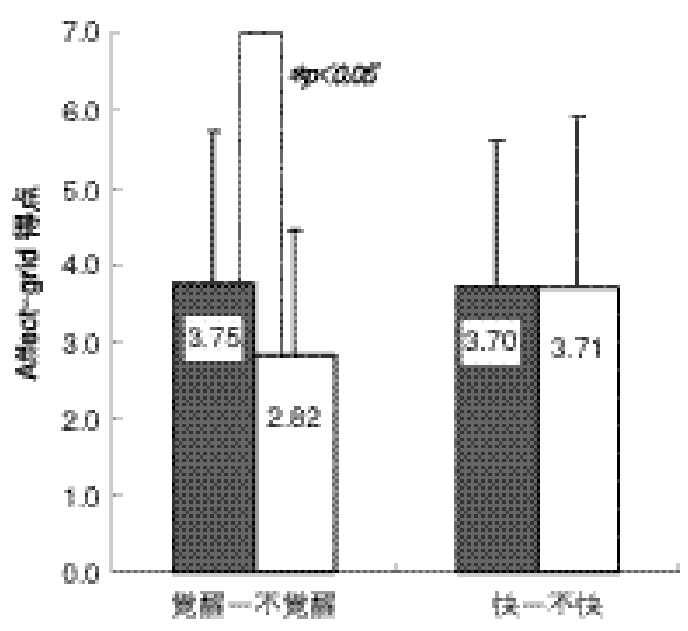

図 3 アフェクトグリッドによる感情の比較

(Trait $48.9 \pm 2.7$ 点). 平均年齢 $21.2 \pm 0.4$ 歳), 健康群

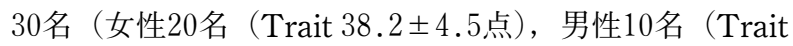
$35.0 \pm 5.5$ 点)。平均年齢 $21.2 \pm 2.2$ 歳）であった。

\section{2. 味覚試験}

ステューデント（Student）の $t$ 検定の結果, 甘味の 感受性が高不安群の方が健康群よりも高いことが明らか となった $(t(61)=2.72, p<0.01)$ 。塩味・酸味に関し ては, 両群間に有意な差は認められなかった。

\section{3 . 気分評定}

アフェクトグリッドによる両群の結果は図 3 に示した。 高不安群と健康群に関しての $t$ 検定の結果, 高不安群が 健康群よりもアフェクトグリッドにおける覚醒-不覚醒 軸の得点が高かった $(t(66)=2.04, p<0.05)$ 。アフェ クトグリッドによる「覚醒」とは，周囲に注意をくばり， 物事を正しく認識しうる状態を示している。快-不快感 に関しては，両群間に有意な差は認められなかった。そ こで，特性不安と「覚醒」に関してピアソン（Pearson） の相関係数を算出し, 無相関検定 (両側) を行った。そ の結果, 正の相関 $(r=0.30, p<0.05)$ が認められた。 すなわち, 特性不安が高い人ほど覚醒していることが明 らかとなった。

\section{4. 自覚的ストレス評価}

CFSIの両群の平均值は図 4 に示した。 $t$ 検定の結果, 高不安群の方が健康群よりも日常的なストレス感が高い ことが明らかとなった $(t(71)=3.02, p<0.05)$ 。また， 特性不安と CFSI 合計点とのピアソンの相関係数算出と 無相関検定 (両側) を行った結果, 特性不安が高い人ほ ぞストレスを強く感じていることが明らかとなった（r $=0.56, p<0.01)$ 。

\section{考察}

本研究において，不安の特性が高い人は甘味の感受性 が高いことが明らかとなった。また，不安の特性が高い 人は慢性的なストレス感と覚醒度が高いことも明らかと 


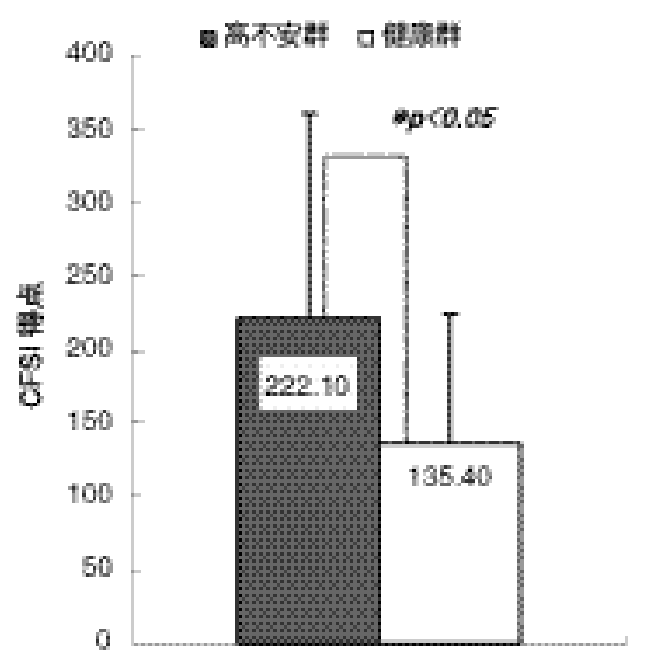

図 4 不安感による慢性ストレス感の違い

なった。

味覚閾值に影響を及ぼすものとしては，年齢・健康状 態・唾液の量や性状の変化などの生理状態, 意欲・興味 などの心理状態, 室温·照明などの環境条件, 検査試料 温度などの実験条件, さらに, 訓練, 知的水準などが挙 げられる14)が, 本研究では, 参加者が同大学の同学年で あり，実験条件も同じであったことなどから，これらが 結果に影響したとは考え難く，不安特性や慢性的なス卜 レス感など, むしろ個人の心理特性の影響であると思わ れる。

本研究で用いた味覚試験の試料の濃度に関しては, 2 群のそれぞれの味覚感受性を比較したので，3味の閾值 の違いは影響しないと考えた。しかし，味覚試験におい ては後味への配慮も必要と考えられ，それぞれの閾值の 違いを考慮することが今後の課題となった。また，本研 究では基本 5 味の内の甘味・塩味・酸味の 3 味について 試験を行ったが，苦味・うま味の 2 味についての検討が なされなかった。苦味については, 基本味の中で最も拒 否反応を引き起こす刺激であるので, 参加者への倫理的 配慮に基づき, 本研究における味覚試験からは除外をし た。また，うま味についてはグルタミン酸・グアニン・ イノシン酸をそれぞれ主成分とした試験が必要であると 考え，参加者を拘束する時間が長時間におよぶと実験そ のものが苦痛となるので, 本研究ではうま味を試験に加 えなかった。しかし，今後うま味を考慮する必要がある かもしれない。

本研究では不安感の高い人は慢性ストレス感が強く, 覚醒度が高かった。井上ら（2003）は，自覚的な不安緊 張に覚醒水準が影響を受ける15) と述べており，カンター ら（1985）は，ストレスが加わると覚醒度が上がり，付 加行動としての食行動を引き起こすとしている16)。また， 覚醒度を上げるテンポの速い音楽, 騒々しい音楽, 大き な音が食行動の速度, 量, 砂糖嗜好を増加させることが わかっている17)。このようにストレッサーに対面した生 体は，自律神経興奮や内分泌系の機能立進などを示すた
め,ストレス感を持つ不安の特性が高い人たちは, 覚醒 感が高まったものと考えられる。一方, 甘味は基本 5 味 のうちで, 最もヒトの生理的特質に由来する味覚要素と されて抢り, 社会的・文化的な食生活環境の影響が少な い18)。そして, 高不安の人たちは誘発されたストレス感 によって, セリエ学説におけるストレッサー対処のひと つとして, 急速な身体活動が要求され, 速やかにエネル ギー源となる糖分を特に必要としたと考えられる。これ らのことは, 本研究の結果に認められるように若者の過 半数が高不安群であることにおいて, 不安感の高い人た ちは糖分を欲し，そのために甘味感受性が高くなったと 思われる19)ことを支持している。この特性が若者の偏食 傾向のひとつの原因ではないかと考えられる。

\section{要 約}

本研究では, 不安の特性が味覚に影響を与えるかを, 官能試験を行って検討したところ，

（1）高不安の人は甘味の感受性が高かった。

(2) 高不安の人はストレス感が高く, 覚醒度も高かっ た。

の結果を得た。味覚に影響を与える大きな要因のひとつ が不安の特性であり, 不安状態やストレスを緩和するこ とが，若者の偏った食行動の改善に慗がることが示唆さ れた。

\section{文献}

1）農林水産省 - 厚生省 ·文部省 : 食生活指針の解説要領 (2000)

2）野口由美，金沢文高，日高三喜夫，永野 純，瀧井正人， 小牧 元, 美根和典, 久保千春: 過敏性腸症候群から神経 性食欲不振症を発症した 1 症例, 心身医学, 38.5, 359-364 (1998)

3）食料 ·農業政策研究センター：食生活変容の潮流, 農山 漁村文化協会（1997）

4）敦見孝子, 本間恵美, 遠藤仁子 : 偏食を生み出す要因に 関する研究一女子短大生の偏食状況一, 東海女子短期大学 紀要，25，37-45 (1999)

5）深見良子, 山崎 緑: 短大生のダイエット経験および食 生活と体調に関する調査, 帝塚山短期大学紀要 人文 · 社 会科学編·自然科学編, 33, 210a-197a (1996)

6）富田 寛：味覚異常の増えている理由, ファルマシア (日本薬学会), 28.11, 1224-1229（1992）

7) 藤内栄太, 矢野里佳, 永井 宏, 吉田公輔, 西村良二 : 医学部学生における摂食態度, ストレス, ストレスコーピ ングについて，福大医紀，213-219（2002）

8) J.Slochower, S.P.Kaplan, and L. Mann,: The Effects of Life Stress and Weight on Mood and Eating. Appetite, 2, 115-125 (1981)

9) D.H.Baucom and P.A.Aiken,: Effect of Depressed Mood on Eating Among Obese and Nonobese Dieting and Nondieting Persons. Journal of Personality and Social Psychology, 41, 577-585 (1981)

10）中里克治, 水口公信: 新しい不安尺度 STAI 日本語版 の作成, 心身医学, 22.2，108-112（1982）

11) Russell, Weiss, and Mendelsohn: Affect-Grid : A Single- 
Item Scale of Pleasure and Arousal, Journal of Personality and Social Psychology, 57.3, 493-502 (1989)

12）越河六郎, 藤井 亀: 労働と健康の調和 CFSI（蓄積的疲 労徵候インデックス）マニュアル, 労働科学研究所出版部, 神奈川 (2002)

13）中野和子, 桑野 薰, 二木栄子 : 調理に関する味質と唾 液分泌について一唾液分泌量と味覚閾值に対する肥瘦の影 響について一, 生活科学, 8.2, 169-180（1969）

14）今中正美, 道本千衣子：女子学生の味覚の変化について, 日本家政学会誌，50.10，1091-1096（1999）

15）井上清子, 相川 博, 山内俊雄 : 不安障害の自律神経活 動々覚醒水準一心拍変動パワースペクトル解析と脳波の $\alpha$ 波振幅変化率を指標として一, 臨床神経生理学, 31.6, 499 -502 (2003)

16) M.B.Cantor and J.F.Wilson,: Feeding the Face: New Directions in Adjunctive Behavior Research, in Affect, Conditioning, and Cognition: Essays on the Determinations of Be- havior, eds. F.R.Brush and J.B.Overmier, Hillsdale,NJ: Lawrence Erlbaum Associates (1985)

17) C.Ferber and M.Cabanac,: Influence of Noise on Gustatory Affective Ratings and Preference for Sweet or Salt, $A p$ petite 8, 229-235 (1987)

18) Lazarus,R.S.and Cohen,J.B., : Environmental Stress. Human behavior and the environment, Current theory and research (1977)

19) Spielberger, C.D.: Theory and research on anxiety. In C.D. Spielberger, ed. Anxiety and Behavior, New York, Academic Press (1966)

$20 ）$ 西丸震哉, 吉川誠次：農林省食料研究報告, 16, 19 (1962)

21) Richard L. Hawkins, M. Inoue, M. Mori and K. Torii : Effect of inhibin, folistain, or activin infusion into the lateral hypothalamus on operant behavior of rats fed lysine deficient diet, Brain research, 704, 1-9 (1995) 